\title{
PERENCANAAN ARSITEKTUR SISTEM INFORMASI PT. MA'SOEM ARIAS DENGAN MENGGUNAKAN ORACLE ENTERPRISE ARCHITECTURE FRAMEWORK
}

\author{
Soni Ayi Purnama \\ STKOM Al Ma'soem \\ soni.mkom@gmail.com
}

\begin{abstract}
Utilization of information systems and information technology is needed in supporting business processes of a company, because the information system is one of the important things in the key to success of a company. Along with the development of information systems have an information system architecture model, where the information system architecture is necessary to plan the information system architecture to be built in the future, where the information system architecture as a spear to improve the competitiveness of a company with other companies.

PT. Ma'soem Arias is one of Pertamina lubricant distributor in West Java. The business activities carried out are to sell Pertamina lubricants to direct customers and direct lubricant procurement from Pertamina's producers. PT. Ma'soem Arias until now in carrying out its business process has not used the information system so needed an Enterprise Architecture planning for PT. Ma'soem Arias.

Enterprise architecture model used in this research is by using Oracle Enterprise Architecture Framework (OEAF) model. The advantages of OEAF is to use object oriented concept, where the concept approaches the problem from the perspective of the object and not the perspective of the functional so it is easy to be understood. The method used is Oracle Architecture Development Process (OADP) method, where OADP method has several stages, ie from start of study about business architecture, architecture vision, current state architecture and future state architecture.

The result of this research is recommendation of information system of PT. Ma'soem Arias is a blueprint for enterprise architecture planning that succeeds in defining 4 main business processes, the data architecture produces 24 entities, 4 applications and for its technological architecture produces technology architecture proposal.
\end{abstract}

Keyword :Enterprise Architecture, Oracle Enterprise Architecture Framework, Oracle Architecture Development Process.

\begin{abstract}
ABSTRAK
Pemanfaatan sistem informasi dan teknologi informasi sangat diperlukan dalam mendukung proses bisnis suatu perusahaan. PT. Ma'soem Arias merupakan salah satu distributor pelumas Pertamina yang ada di Jawa Barat. Kegiatan usaha yang dijalankan adalah menjual pelumas Pertamina ke pelanggan langsung dan pengadaan pelumas langsung dari produsen Pertamina. PT. Ma'soem Arias hingga kini dalam melaksanakan proses bisnisnya belum menggunakan sistem informasi sehingga diperlukanlah sebuah perencanaan Enterprise Architecture untuk PT. Ma'soem Arias.

Model enterprise architecture yang digunakan dalam penelitian ini yaitu dengan menggunakan model Oracle Enterprise Architecture Framework (OEAF). Kelebihan OEAF ini yaitu menggunakan konsep object oriented, dimana konsep ini melakukan pendekatan terhadap masalah dari perspektif obyek dan tidak perspektif terhadap fungsional sehingga mudah untuk dipahami. Metode yang digunakan yaitu metode Oracle Architecture Development Process (OADP).
\end{abstract}


Hasil dari penelitian ini yaitu rekomendasi sistem informasi PT. Ma'soem Arias berupa blue print perencanaan enterprise architecture yakni berhasil mendefinisikan 4 proses bisnis utama, pada arsitektur data menghasilkan 24 entitas, 4 aplikasi serta untuk arsitektur teknologinya menghasilkan usulan arsitektur teknologi.

Kata Kunci: Arsitektur Enterprise, Oracle Enterprise Architecture Framework, Proses Pengembangan Arsitektur Oracle.

\section{PENDAHULUAN}

\subsection{Latar Belakang Masalah}

Perkembangan sistem informasi dan teknologi informasi begitu pesat, dimana pemanfaatan sistem informasi dan teknologi informasi tidak hanya sebagai penunjang melainkan sebagai solusi bisnis dalam sebuah perusahaan. Di dalam perkembangan sistem informasi ini terdapat sebuah model arsitektur sistem informasi yang merupakan kunci utama dalam proses pengembangan sistem informasi karena digunakan sebagai strategi implementasi sistem informasi. Arsitektur sistem informasi ini diperlukan untuk merencanakan arsitektur sistem informasi yang akan dibangun pada masa depan, dimana arsitektur sistem informasi sebagai tombak untuk meningkatkan daya saing sebuah perusahaan dengan perusahaan lainnya.

Salah satu metode untuk membuat perencanaan arsitektur sistem/Enterprise Architecture Planning (EAP) yaitu Oracle Enterprise Architecture Framework (OEAF). OEAF merupakan sebuah framework untuk arsitektur perusahaan yang dengan pendekatan dengan ruang linkup yang begitu luas dalam menentukan sebuah perencanaan, perancangan dan pelaksanaan arsitektur sistem informasi dalam sebuah perusahaan. Kelebihan OEAF ini yaitu menggunakan konsep object oriented, dimana konsep ini melakukan pendekatan terhadap masalah dari perspektif obyek dan tidak perspektif terhadap fungsional sehingga mudah untuk dipahami. Konsep object oriented begitu populer sekarang ini dalam mengembangkan sistem informasi berbasis teknologi informasi.

PT. Ma'soem Arias merupakan perusahaan yang bergerak dalam bidang penjualan Pelumas Pertamina yang beralamatkan di Jl. Raya Cileunyi KM. 19 Cileunyi Kabupaten Bandung. PT. Ma'soem Arias merupakan salah satu Distributor Pelumas Pertamina di wilayah Jawa Barat. Dalam perjalanannya PT. Ma'soem Arias hingga kini belum mempunyai pendefinisian yang jelas tentang arsitektur data, proses dan jaringan sistem informasi pada proses bisnis yang dijalankan. Oleh karena itu, PT. Ma'soem Arias belum memiliki sistem informasi yang dapat memenuhi kebutuhan-kebutuhan bisnis strategi organisasi.

\subsection{Rumusan Masalah}

Rumusan masalah akan penulis tuangkan ke dalam beberapa pertanyaan sebagai berikut:

1. Bagaimana merancang arsitektur sistem informasi untuk PT. Ma'soem Arias dengan menggunakan Oracle Enterprise Architecture Framework?

2. Bagaimana membuat rekomendasi sistem informasi yang dibutuhkan PT. Ma'soem Arias?

\subsection{Tujuan Penelitian}

Tujuan penelitian adalah sebagai berikut :

1. Membuat perencanaan arsitektur sistem informasi pada PT. Ma'soem Arias dengan menggunakan Oracle Enterprise Architecture Framework.

2. Membuat rekomendansi sistem informasi yang dibutuhkan PT. Ma'soem Arias.

\section{METODOLOGI}


Langkah-langkah yang terdapat didalam penelitian dimulai dari proses pengumpulan data berupa studi literature, wawancara dan observasi. Setelah pengumpulan data, maka dilakukan analisis menggunakan metode SWOT dan value chain. Setelah selesai dengan tahap analisis sistem dilanjutkan tahap perencangan arsitektur menggunakan OEAF. Berikut di bawah ini kerangka penelitan yang peneliti tuangkan :

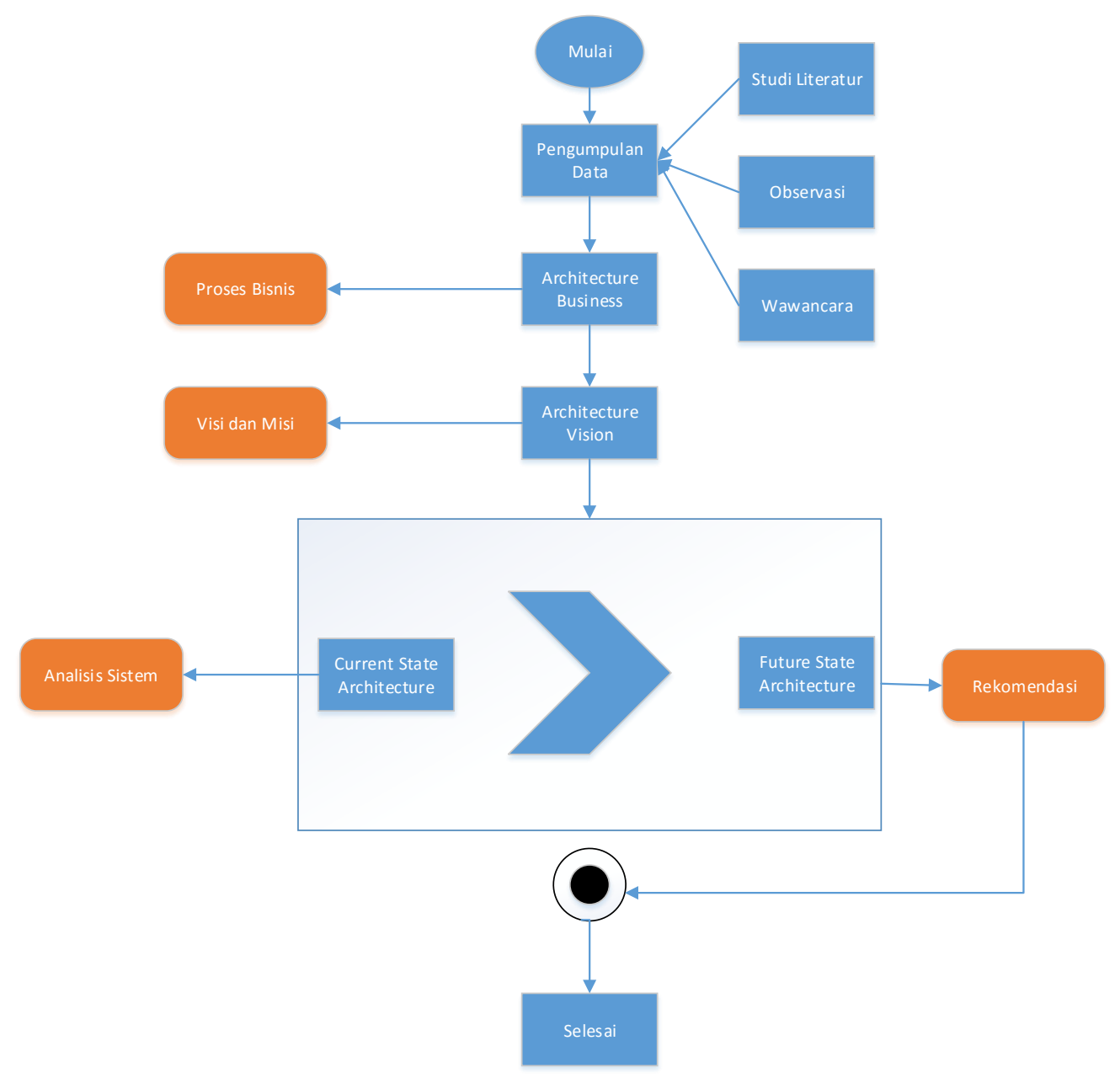

Keterangan :

Gambar 1 Kerangka Penelitian

1. Pengumpulan data merupakan tahap awal dalam penlitian ini, dimana pada tahap ini dilakukan studi literatur, observasi dan wawancara.

2. Metodologi yang digunakan yaitu menggunakan OEAF yang terdiri dari tiga tahap diantaranya:

a. Architecture Business dengan hasil keluarannya sebuah arsitektur bisnis pada organisasi.

b. Architecture Vision dengan hasil keluarannya yaitu visi organisasi.

c. Current State Architecture dengan hasil keluarannya analisis sistem yang sedang berjalan beserta usulannya.

d. Future State Architecture dengan keluarannya yaitu sebuah rekomendasi untuk organisasi/perusahaan tempat penelitian.

\section{ANALISA DAN PERANCANGAN SISTEM}

\subsection{Business Architecture}

Pada tahap ini menjelaskan proses bisnis sedang berjalan di PT. Ma'soem Arias. Proses bisnis utama yang dijalankan di PT. Ma'soem Arias meliputi pembelian, penjualan dan 
pemasaran dan aktivitas pendukung meliputi pengelolaan sumber daya manusia (SDM), keuangan dan teknologi informasi/sistem informasi. Pada tahapan ini juga terdapat sebuah analis SWOT untuk mengetahui kekuatan, kelemahan, peluang dan ancaman pada PT. Ma'soem Arias.

\subsubsection{Analisis Value Chain}

Berikut Value Chain PT. Ma'soem Arias dituangkan pada gambar 2.

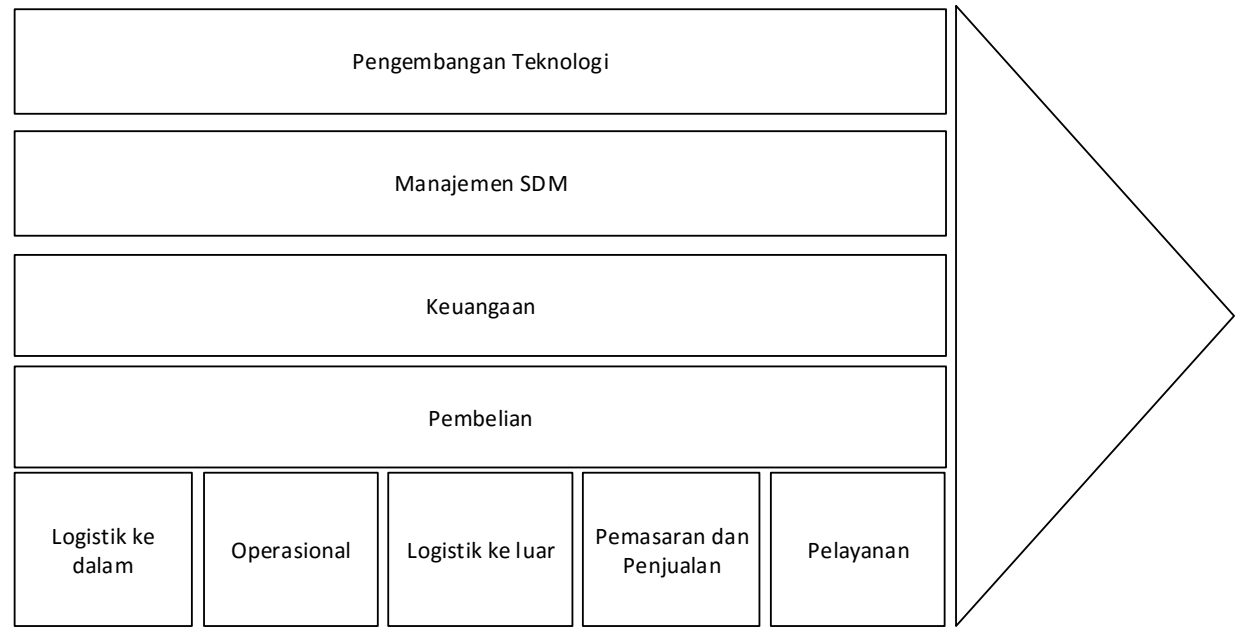

Gambar 2 Value Chain PT. Ma'soem Arias

\subsubsection{Analisis SWOT}

Penjabaran analisa SWOT di PT. Ma'soem Arias adalah dituangkan dalam tabel 1 dibawah ini.

Tabel 1 Matrik Analisis SWOT

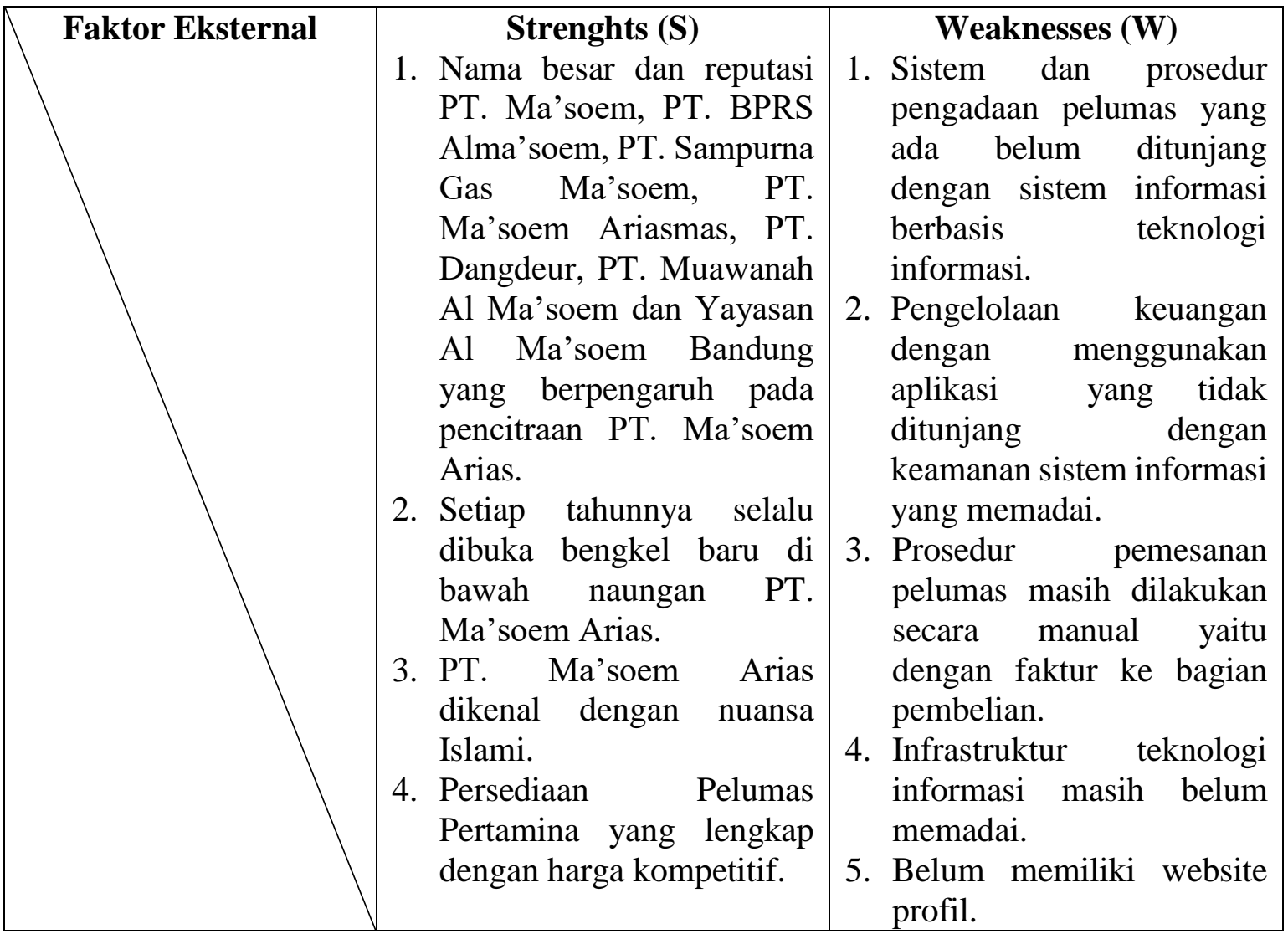




\begin{tabular}{|c|c|c|}
\hline Faktor Internal & & \\
\hline Opportunities (O) & Strategi SO & Strategi WO \\
\hline $\begin{array}{l}\text { 1. Banyaknya industri } \\
\text { dan perusahaan yang } \\
\text { menjadi pelanggan } \\
\text { tetap. } \\
\text { 2. Banyaknya bengkel } \\
\text { yang menjadi } \\
\text { pelanggan tetap. } \\
\text { 3. Adanya perkembangan } \\
\text { perkembi informasi } \\
\text { teknologi dapat } \\
\text { yang semakin pesat } \\
\text { yang } \\
\text { memudahkan } \\
\text { penyampaian } \\
\text { informasi dan } \\
\text { promosi PT. } \\
\text { Ma'soem Arias }\end{array}$ & $\begin{array}{l}\text { 1. Pembuatan website profil } \\
\text { PT. Ma'soem Arias untuk } \\
\text { meningkatkan jangkauan } \\
\text { pemasaran. } \\
\text { 2. Pembuatan sistem informasi } \\
\text { penjualan yang termasuk di } \\
\text { dalamnya pemesanan secara } \\
\text { online dan real time. }\end{array}$ & $\begin{array}{l}\text { 1. Membuat sistem } \\
\text { pengelolaan SDM. } \\
\text { 2. Membuat sistem informasi } \\
\text { penjualan berbasis website } \\
\text { dan termasuk profil } \\
\text { perusahaan } \\
\text { 3. Membuat sistem informasi } \\
\text { pengadaan pelumas yang } \\
\text { terdiri dari pembelian dan } \\
\text { pengelolaan stok pelumas. } \\
\text { 4. Membuat sistem informasi } \\
\text { keuangan dengan } \\
\text { keamanan sistem yang } \\
\text { memadai }\end{array}$ \\
\hline Threats (T) & Strategi ST & Strategi WT \\
\hline $\begin{array}{l}\text { 1. Jarak antara } \\
\text { distributor pelumas } \\
\text { Pertamina lainnya } \\
\text { berdekatan. } \\
\text { 2. Perkembangan } \\
\text { teknologi informasi } \\
\text { yang semakin } \\
\text { semakin pesat yang } \\
\text { harus diimbangi } \\
\text { dengan kompetensi } \\
\text { khusus SDM PT. } \\
\text { Ma'soem Arias. }\end{array}$ & $\begin{array}{l}\text { 1. Pembuatan } \\
\text { kepegawaian } \\
\text { mengelola SDM dan untuk } \\
\text { meningkatkan kualitas } \\
\text { SDM } \\
\text { 2. Diadakan pelatihan khusus } \\
\text { untuk karyawannya untuk } \\
\text { penggunaan teknologi } \\
\text { informasi dan sistem } \\
\text { informasi }\end{array}$ & $\begin{array}{l}\text { 1. Membuat sistem informasi } \\
\text { penjualan yang dapat } \\
\text { diakses tanpa batas oleh } \\
\text { ruang dan waktu } \\
\text { 2. Melakukan penambahan } \\
\text { SDM bidang teknologi } \\
\text { informasi dan sistem } \\
\text { informasi. }\end{array}$ \\
\hline
\end{tabular}

\subsubsection{Pemetaan Layanan, Proses dan Fungsi Bisnis}

Berikut di bawah ini layanan bisnis, proses bisnis dan fungsi bisnis di PT. Ma'soem Arias dituangkan pada tabel 2 dibawah ini.

Tabel 2 Pemetaan Layanan Bisnis, Proses Bisnis dan Fungsi Bisnis di PT. Ma'soem Arias

\begin{tabular}{|l|l|l|l|}
\hline No & $\begin{array}{c}\text { Layanan } \\
\text { Bisnis }\end{array}$ & \multicolumn{1}{|c|}{ Proses Bisnis } & \multicolumn{1}{c|}{ Fungsi Bisnis } \\
\hline 1 & Pengadaan & Persediaan & Pelaporan Data Persediaan \\
\cline { 3 - 4 } & & & Pembuatan Purchase Order \\
\cline { 3 - 4 } & & & Pemberian Nota Pemesanan Valid \\
\hline
\end{tabular}




\begin{tabular}{|c|c|c|c|}
\hline No & $\begin{array}{c}\text { Layanan } \\
\text { Bisnis }\end{array}$ & Proses Bisnis & Fungsi Bisnis \\
\hline & & & Penerimaan Nota Pembeliaan \\
\hline & & & Pelaporan Data Pengadaan \\
\hline & & Penerimaan & Pengecekan Kualitas Barang \\
\hline & & & Pencatatan Barang Masuk \\
\hline & & & Pencatatan Retur \\
\hline & & & Pelaporan Data Masuk \\
\hline \multirow[t]{10}{*}{2} & \multirow{10}{*}{ Penjualan } & \multirow{5}{*}{$\begin{array}{l}\text { Penerimaan } \\
\text { Pesanan/Selling Order }\end{array}$} & Pengecekan Pemesanan \\
\hline & & & Konfirmasi Pembayaran \\
\hline & & & Memberikan Nota Penjualan \\
\hline & & & Pencatatan Pesanan \\
\hline & & & Pelaporan Pesanan \\
\hline & & \multirow[t]{3}{*}{ Pengiriman } & Pemesanan \\
\hline & & & Penerimaan \\
\hline & & & Konfirmasi Pembayaran \\
\hline & & \multirow[t]{2}{*}{ Pemasaran } & Penyediaan Informasi Perusahaan \\
\hline & & & Penyediaan Informasi Data Pelumas \\
\hline \multirow[t]{7}{*}{3} & \multirow[t]{7}{*}{ Kepegawaian } & \multirow[t]{2}{*}{ Presensi } & Pendataan Data Presensi \\
\hline & & & Pelaporan Presensi Karyawan \\
\hline & & \multirow[t]{5}{*}{ Penggajian } & Pengelolaan Data Karyawan \\
\hline & & & Pengelolaan Data Golongan \\
\hline & & & Pengelolaan Data Jabatan \\
\hline & & & Pengelolaan Penggajian \\
\hline & & & Pelaporan Data Gaji \\
\hline \multirow[t]{3}{*}{4} & \multirow[t]{3}{*}{ Keuangan } & \multirow[t]{3}{*}{ Pelaporan Keuangan } & Pencatatan Pendapatan \\
\hline & & & Pengelolaan Akuntansi Keuangan \\
\hline & & & \begin{tabular}{|lll} 
Pembuatan & Laporan & Akuntansi \\
Keuangan & & \\
\end{tabular} \\
\hline
\end{tabular}

\subsection{Architecture Vision}

Berdasarkan analisis Value Chain dan SWOT analisis maka dapat dijabarkan bahwa visi arsitektur PT. Ma'soem Arias yaitu sistem informasi enterprise untuk mendukung bisnis inti yang dijalankan PT. Ma'soem Arias.

\subsubsection{Struktur Organisasi Usulan}

Berikut struktur organisasi usulan untuk PT. Ma’soem Arias. 


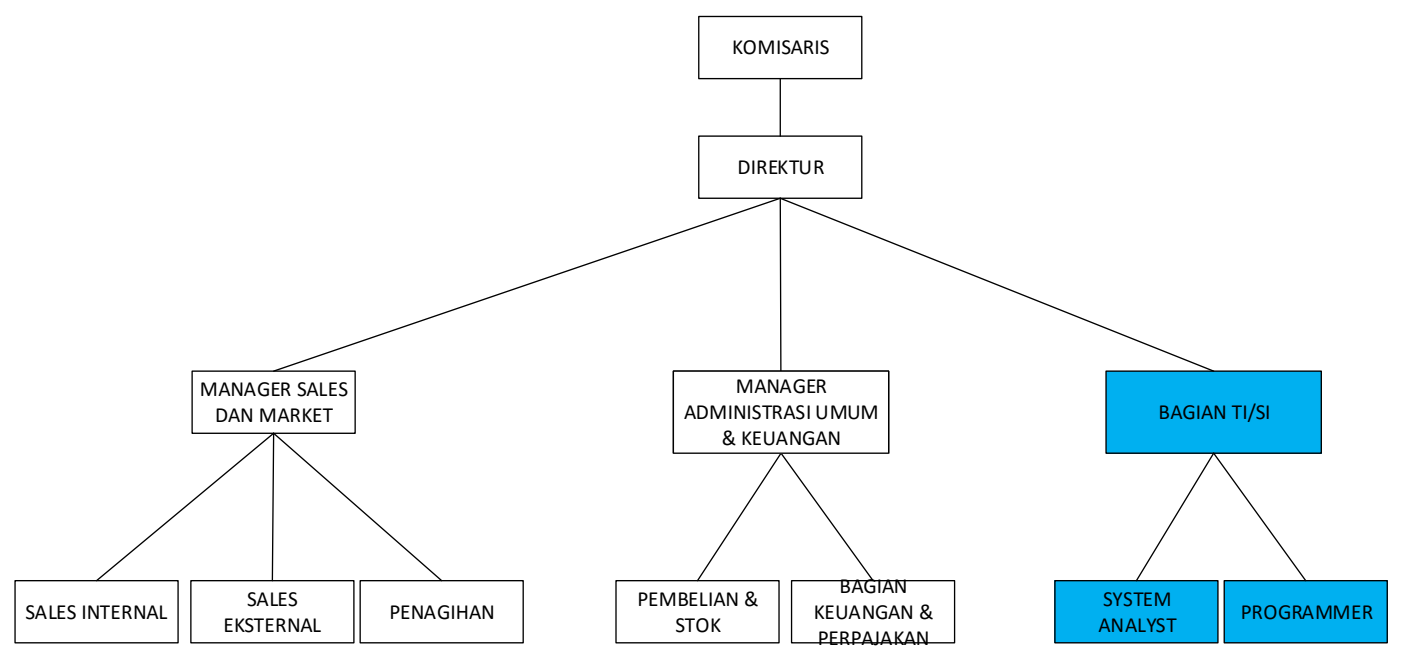

Gambar 3 Struktur Organisasi PT. Ma'soem Arias (Penelitian, 2017)

Berikut tugas dan wewenang setiap bagian struktural pada PT. Ma'soem Arias :

1. Bagian TI/SI merupakan kepala bagian teknologi informasi/sistem informasi, bagian TI/SI bertanggung jawab untuk melakukan pengembangan, pengimplementasian dan perawatan sumber daya teknologi informasi/sistem informasi di PT. Ma'soem Arias.

2. System Analyst berperan dalam mendesain sistem secara keseluruhan, baik dari segi basis data, aplikasi dan teknologi informasi/sistem informasi pendukung. System Analys merancang sistem dengan mengumpulkan semua informasi yang dibutuhkan dan pengembangan sistem informasi sesuai dengan rencana.

3. Programmer berperan dalam tahap pembangunan dan pengembangan sistem informasi yang telah didesain oleh system analyst. Dengan adanya acuan desain sistem sistem dari system analyst diharapkan programmer dapat mengerjakan dan menyelesaikan pembuatan sistem informasi secara tepat dan sesuai dengan perencanaan yang telah dibuat.

\subsubsection{Pelatihan yang Diusulkan}

Pelatihan yang diusulkan untuk bagian TI/SI yaitu system analyst dan programmer agar dapat melaksanan tugasnya dengan baik. Berikut ini daftar pelatihan usulan dituangkan pada tabel3.

Tabel 3 Daftar Pelatihan yang Diusulkan

\begin{tabular}{|c|l|l|l|l|}
\hline No & \multicolumn{1}{|c|}{ Jabatan } & \multicolumn{4}{|c|}{ Jenis Pelatihan } \\
\hline 1 & System Analyst & $\begin{array}{l}\text { Pelatihan yang diberikan adalah untuk mengembangkan } \\
\text { kemampuan untuk menganalisis dalam perencanaan dan } \\
\text { pengembangan sistem. }\end{array}$ \\
\hline 2 & Programmer & $\begin{array}{l}\text { Pelatihan yang diberikan adalah untuk mengembangkan } \\
\text { kemampuan programming sehingga dapat mengembangkan } \\
\text { aplikasi sesuai dengan tujuan bisnis. }\end{array}$ \\
\hline
\end{tabular}

\subsubsection{Hubungan Stakeholder dengan Aktivitas Organisasi}

Proses bisnis di PT. Ma'soem Arias memiliki beberapa stakeholder yang memeliki kepentingan terhadap proses bisnis utama dan pendukung. Berikut penjelasan hubungan stakeholder dengan aktivitas organisasi dapat dilihat pada tabel 4. 


\begin{tabular}{|c|c|c|c|}
\hline No & Aktivitas & Stakeholder & Keterbatasan \\
\hline \multirow[t]{3}{*}{1} & \multirow[t]{3}{*}{ Persediaan } & $\begin{array}{l}\text { Bagian administrasi } \\
\text { umum dan keuangan }\end{array}$ & $\begin{array}{lcr}\text { Mengawasi } & \text { aktivitas } & \text { staf } \\
\text { administrasi } & \text { umum dalam } \\
\text { pengelolaan persediaan pelumas }\end{array}$ \\
\hline & & $\begin{array}{l}\text { Bagian pembelian dan } \\
\text { stok gudang }\end{array}$ & $\begin{array}{l}\text { Melakukan kegiatan pengelolaan } \\
\text { persediaan pelumas yaitu mengelola } \\
\text { data pelumas, supplier, purchase } \\
\text { order, penerimaan dan pembayaran. }\end{array}$ \\
\hline & & Bagian keuangan & $\begin{array}{l}\text { Melihat pelaporan dan melakukan } \\
\text { pengelolaan laporan akuntansi }\end{array}$ \\
\hline \multirow[t]{4}{*}{2} & \multirow[t]{4}{*}{ Penjualan } & $\begin{array}{lll}\begin{array}{l}\text { Manager } \\
\text { marketing }\end{array} & & \\
\end{array}$ & $\begin{array}{l}\text { Melakukan pengawasan terhadap } \\
\text { aktivitas penjualan. }\end{array}$ \\
\hline & & Sales internal & \multirow{2}{*}{$\begin{array}{l}\text { Melakukan pengelolaan terhadap } \\
\text { selling order, penjadwalan } \\
\text { pengiriman pelumas, pengelolaan } \\
\text { data pelanggan, konfirmasi } \\
\text { pembayaran dan mengelola }\end{array}$} \\
\hline & & Sales eksternal & \\
\hline & & Penagihan & $\begin{array}{l}\text { Melakukan penagihan terhadap } \\
\text { pembayaran pelanggan } \\
\text { kredit macet. }\end{array}$ \\
\hline 3 & Kepegawaian & $\begin{array}{l}\text { Bagian administrasi } \\
\text { umum dan keuangan }\end{array}$ & $\begin{array}{l}\text { Melakukan pengelolaan terhadap } \\
\text { data golongan, jabatan, presensi dan } \\
\text { penggajian }\end{array}$ \\
\hline \multirow[t]{2}{*}{4} & \multirow[t]{2}{*}{ Keuangan } & $\begin{array}{l}\text { Bagian administrasi } \\
\text { umum dan keungan }\end{array}$ & $\begin{array}{l}\text { Melakukan pengawasan terhadap } \\
\text { aktivitas akuntansi }\end{array}$ \\
\hline & & $\begin{array}{l}\text { Bagian keuangan dan } \\
\text { perpajakan }\end{array}$ & $\begin{array}{l}\text { Melakukan pengelolaan terhadap } \\
\text { akuntansi keuangan }\end{array}$ \\
\hline
\end{tabular}

\subsection{Current State Architecture}

Pada tahapan current state architecture menjelaskan tentang sistem yang sedang berjalan saat ini, PT. Ma'soem Arias masih menjalankan proses bisnisnya dengan menggunakan cara manual. Berikut di bawah ini analisis sistem informasi di PT. Ma'soem Arias yang digambarkan melalui alat bantu permodelan UML yaitu use case model :

1. Use case sistem informasi pengadaan 


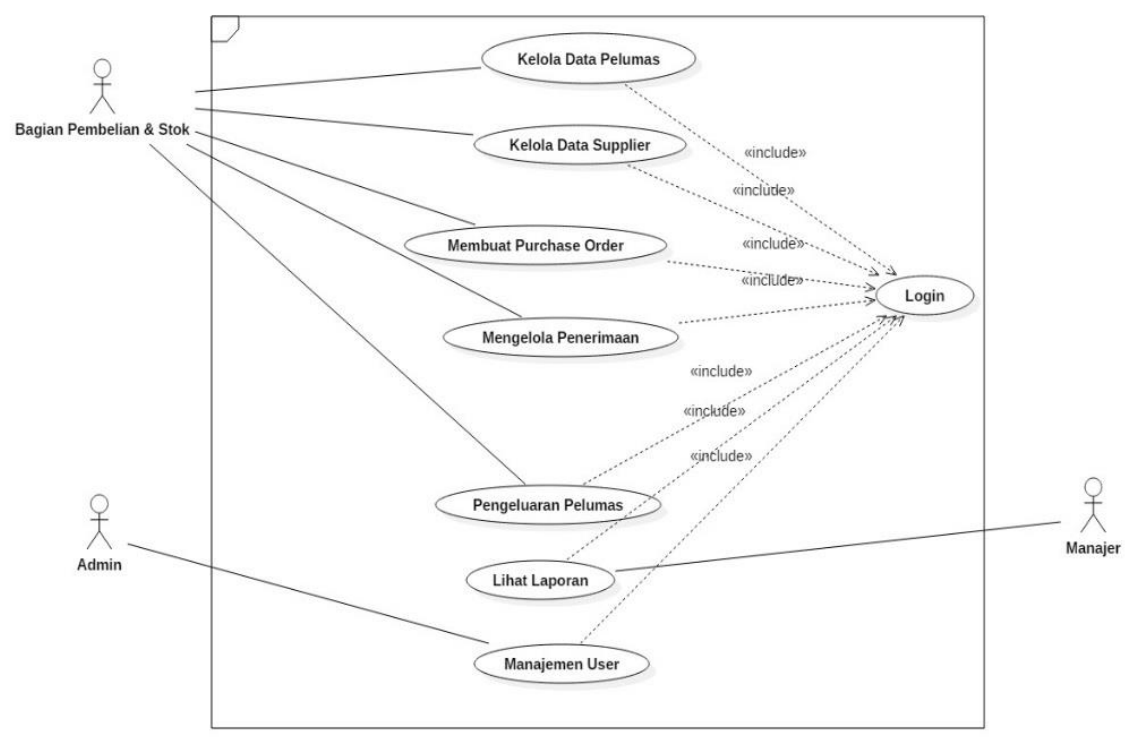

Gambar 4 Use Case Sistem Informasi Pengadaan

Fungsi bisnis yang pada gambar diatas, dengan model use case yaitu fungsi bisnis yang terdapat pada proses bisnis pengadaan dimana terdapat 3 aktor yaitu admin sebagai administrator, manager dan bagian pembelian dan stok. Proses bisnis yang dijalankan meliputi pengelolaan data pelumas, kelola data supplier, membuat purchace order, mengelola penerimaan, pengeluaran pelumas, melihat laporan dan manajemen user.

Kemasan pelumas yang terdiri dari kemasan dus, botol dan drum dengan volume yang berbeda-beda dan supplier utamanya yaitu PT. Pertamina (Persero). Proses purchase order yang dilakukan oleh bagian pembelian dan stok dimana stok pelumas sudah berada pada stok minimum. Setelah dilakukan purchase order, PT. Ma'soem Arias melakukan proses penerimaan pelumas, setalah itu dilakukan pembayaran dan melakukan pengeluaran pelumas sesuai kebutuhan bagian penjualan. Pelaporan yang dihasilkan berupa laporan data stok pelumas, supplier, laporan purchase order, penerimaan, pembayaran dan pengeluaran pelumas.

2. Use case sistem informasi penjualan

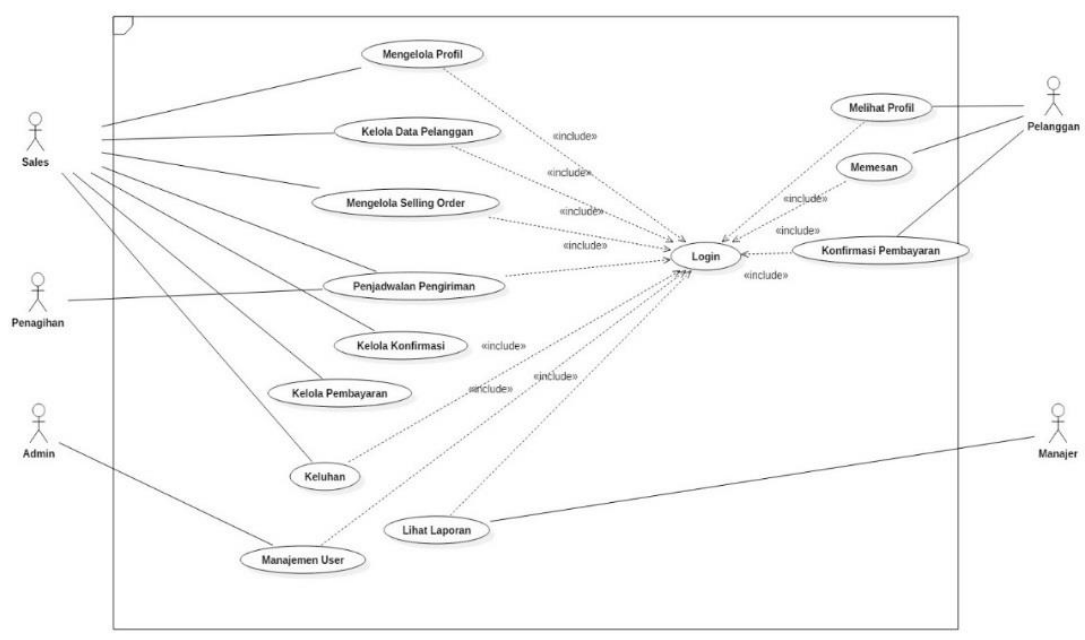

Gambar 5 Use Case Sistem Informasi Penjualan

Fungsi bisnis pada gambar diatas, dengan model use case yaitu fungsi bisnis yang terdapat pada sistem informasi penjualan dimana terdapat 3 aktor yaitu admin sebagai 
administrator, manager dan bagian sales dan marketing. Proses bisnis yang dijalankan meliputi pengelolaan data profil perusahaan, kelola data pelanggan, selling order, penjadwalan pengiriman, kelola konfirmasi pembayaran yang dilakukan pelanggan, keluhan pelanggan, manajemen user dan pembuatan laporan meliputi laporan data pelanggan, selling order, penjadwalan, pengiriman, konfirmasi pembayaran dan penjualan.

3. Use Case sistem informasi kepegawaian

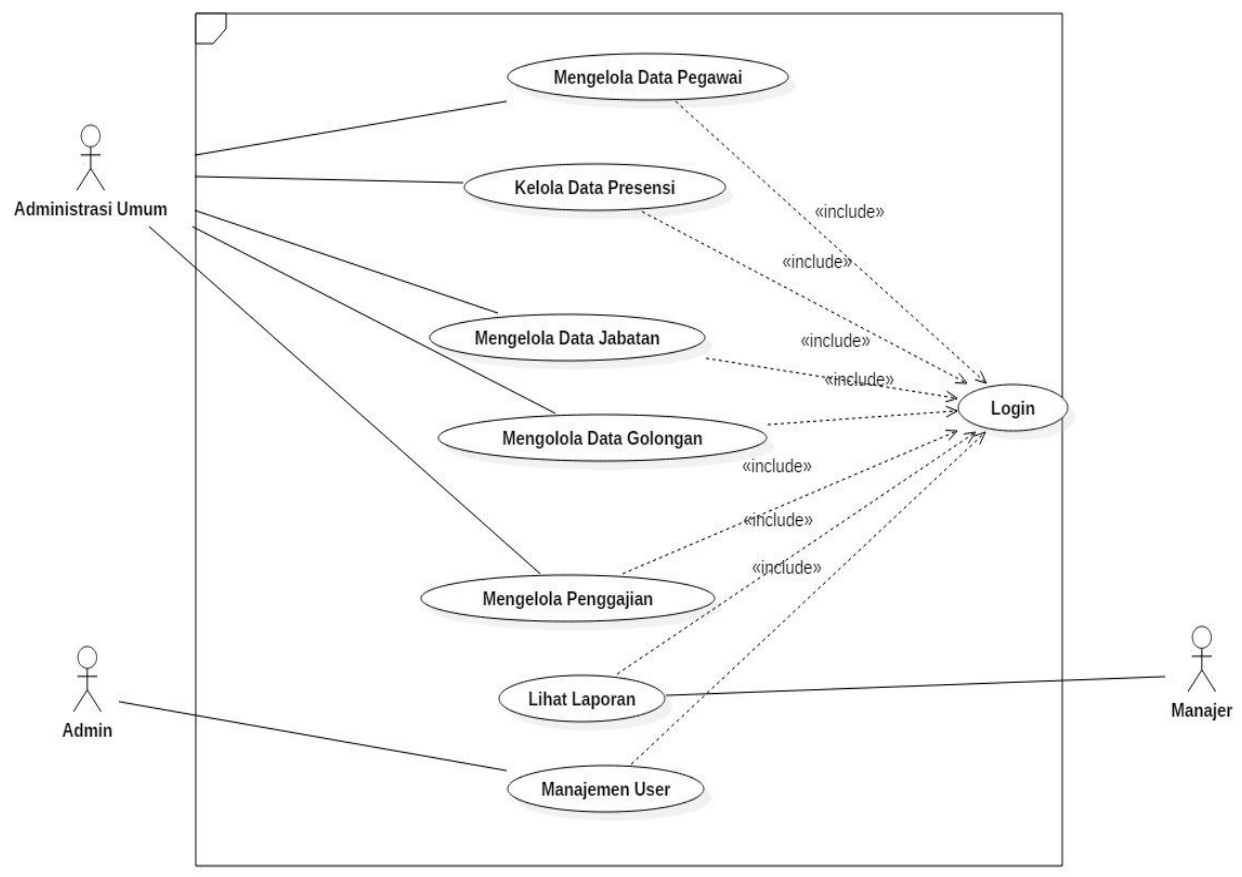

Gambar 6 Use Case Sistem Informasi Kepegawaian

Fungsi bisnis pada gambar diatas, dengan model use case yaitu fungsi bisnis yang terdapat pada sistem informasi kepegawaian dimana terdapat 3 aktor yaitu admin sebagai administrator, manager dan bagian administrasi umum. Proses bisnis yang dijalankan meliputi pengelolaan data pegawai, presensi, jabatan, golongan, penggajian, manajemen user, laporan data pegawai, golongan, jabatan penggajian.

roses penggajian di PT. Ma'soem Arias mengacu pada sistem golongan sesuai surat keputusan pemegang saham, dimana sistem golongan ini terdapat 5 golongan diantaranya gologan 1 sampai dengan 5. Elemen gaji diantaranya gaji pokok, uang makan, transport, insentif dan potongan sesuai dengan ketidakhadiran karyawan. Pengajian ini dibayarkan 2 kali dalam 1 bulan yaitu pada tanggal 1 dan tanggal 20. Proses awal yang dilakukan adalah pengolahan data pegawai setelah itu pengelolahan data gologan, jabatan, presensi dan penggajian.

4. Use case sistem informasi keuangan 


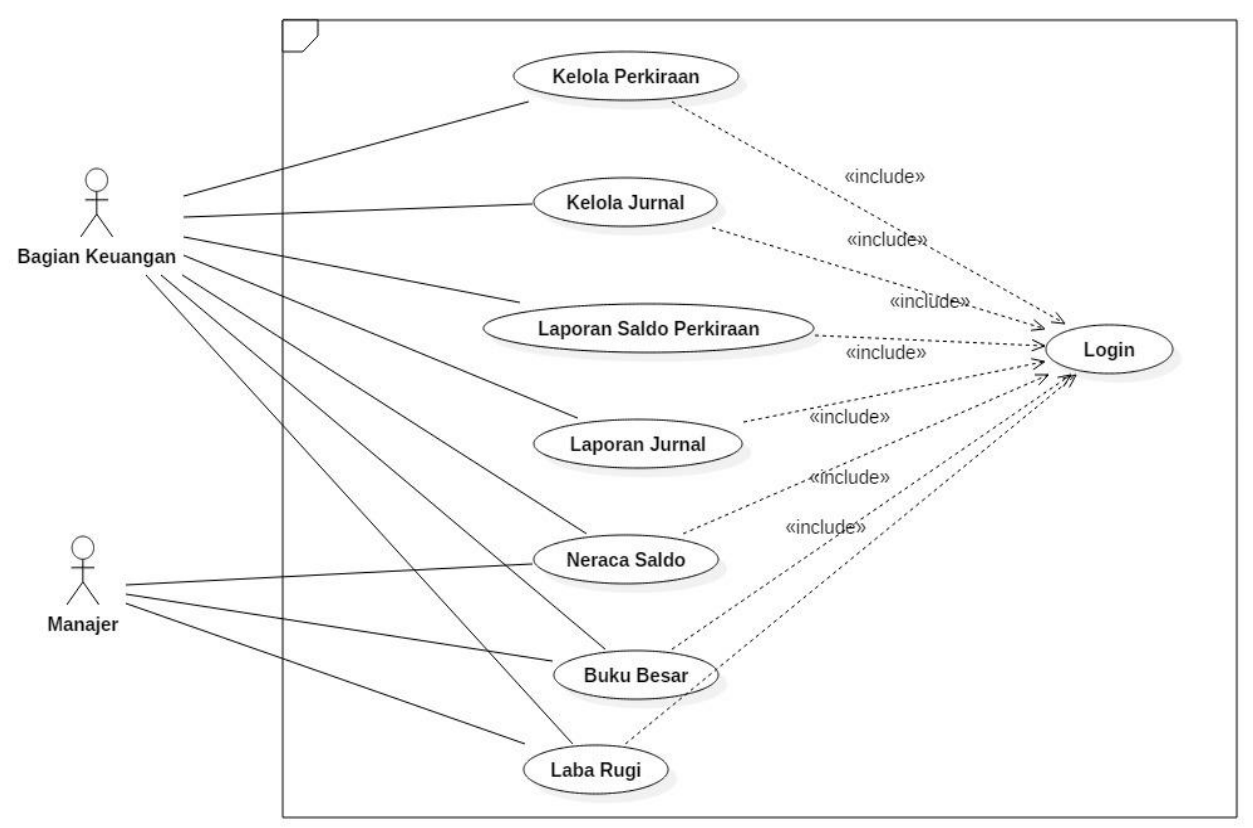

Gambar 7 Use Case Sistem Informasi Keuangan

Fungsi bisnis pada gambar diatas, dengan model use case yaitu fungsi bisnis yang terdapat pada sistem informasi keuangan dimana terdapat 1 aktor yaitu bagian keuangan dimana bagian keuangan mengelola data perkiraan dan jurnal dengan laporan keungan meliputi laporan jurnal, neraca saldo, buku besar dan laba rugi.

\subsection{Future State Architecture}

Pada tahapan ini dilakukan dengan membagi menjadi tiga tahapan yaitu pemodelan arsiterktur data, pemodelan aplikasi dan teknologi. Pada pelaksanaannya tidak terpaku kepada arsitektur data terlebih dahulu selanjutnya arsitektur aplikasi, akan tetapi bisa mendahulukan arsitektur aplikasi dan dilanjutkan dengan arsitektur data dan arsitektur teknologi.

\subsubsection{Arsitektur Aplikasi}

Berikut ini penjelasan dari masing-masing rancangan aplikasi dan daftar aplikasi yang dibutuhkan oleh PT. Ma'soem Arias yang tertuang dalam tabel 4.

Tabel 4 Katalog Portofolio Aplikasi PT. Ma'soem Arias

\begin{tabular}{|c|l|l|l|}
\hline No & Nama Aplikasi & \multicolumn{1}{|c|}{ Fungsi } & \multicolumn{1}{|c|}{ Cakupan } \\
\hline 1 & $\begin{array}{l}\text { Sistem Informasi } \\
\text { Pengadaan }\end{array}$ & $\begin{array}{l}\text { Mengelola dan pengawasan } \\
\text { terehadap stok pelumas, mengelola } \\
\text { data supplier, purchase order, } \\
\text { penerimaan, pembayaran dan } \\
\text { pengeluaran ke bagian penjualan. }\end{array}$ & $\begin{array}{l}\text { Internal : Banian } \\
\text { Pembelian/stok dan } \\
\text { manajer }\end{array}$ \\
\hline 2 & $\begin{array}{l}\text { Sistem Informasi } \\
\text { Penjualan }\end{array}$ & $\begin{array}{l}\text { Mengelola data pelanggan, } \\
\text { pesanan pelumas, penjadwalan } \\
\text { pengiriman, pembayaran, keluhan } \\
\text { pelanggan dan mengelola profil } \\
\text { perusahaan. }\end{array}$ & $\begin{array}{l}\text { Internal :Bagian sales, } \\
\text { penagihan, manajer } \\
\text { dan Eksternal } \\
\text { Pelanggan }\end{array}$ \\
\hline 3 & $\begin{array}{l}\text { Sistem Informasi } \\
\text { Kepegawaian }\end{array}$ & $\begin{array}{l}\text { Mengelola data pegawai, jabatan, } \\
\text { golongan, presensi dan penggajian. }\end{array}$ & $\begin{array}{l}\text { Internal : Administrasi } \\
\text { umum dan manajer }\end{array}$ \\
\hline
\end{tabular}




\begin{tabular}{|c|l|l|l|c|}
\hline 4 & $\begin{array}{l}\text { Sistem Informasi } \\
\text { Keuangan }\end{array}$ & $\begin{array}{l}\text { Mengelola penjurnalan ayat-ayat } \\
\text { transaksi. }\end{array}$ & $\begin{array}{l}\text { Internal : Bagian } \\
\text { keuangan dan manajer }\end{array}$ \\
\hline
\end{tabular}

Berikut deployment diagram PT. Ma’soem Arias dituangkan pada gambar 8.

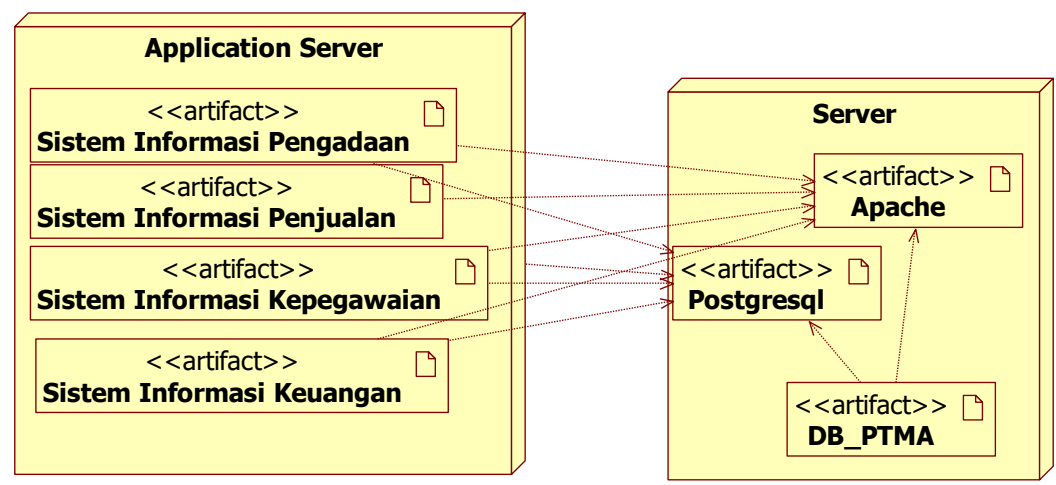

Gambar 8 Deployment Diagram PT. Ma'soem Arias

\subsubsection{Arsitektur Data}

Permodelan yang digunakan dalam menggambarkan arsitektur data PT. Ma'soem Arias yaitu dengan menggunakan class diagram, dimana class diagram menggambarkan model konseptual basis data dan entitas data yang diutangkan dalam bentuk atribut berikut ini.

1. Class Diagram Pengadaan

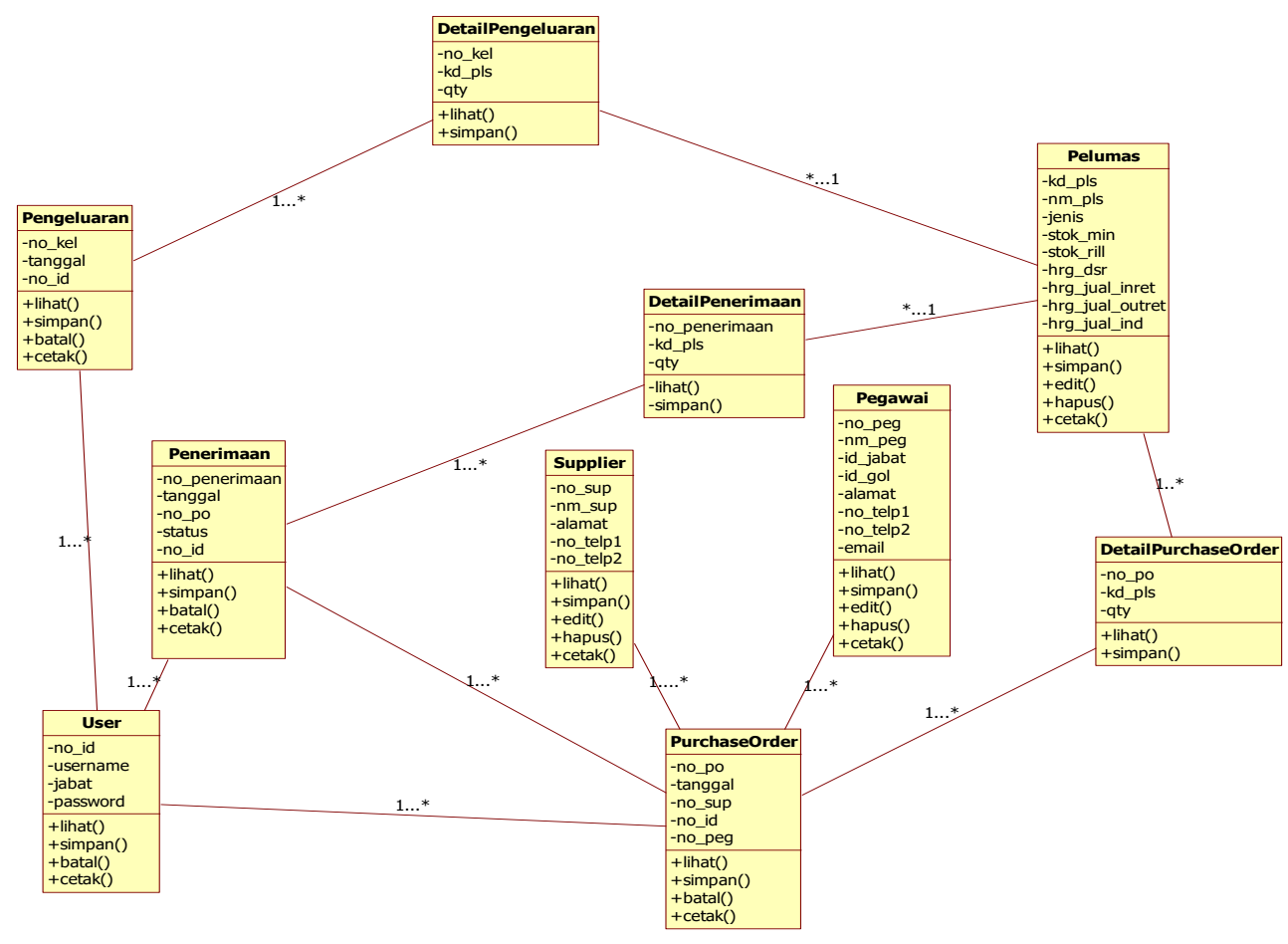

Gambar 9 Class Diagram Sistem Informasi Pengadaan

Arsitektur data yang digambarkan pada gambar diatas, merupakan arsitektur data pada sistem informasi pengadaan pelumas yang terdiri dari class, atribut dan method. Class dibangun untuk membangun sebuah objek baru dalam sistem ini. Class diagram terdiri dari class pelumas, supplier, purchase order, detailpurchaseorder, penerimaan, detailpenerimaan, pengeluaran dan detaipengeluaran dan user. Atribut terletak pada bagian tengah bagan class dan method berada pada bagian bawah bagan class. 
2. Class Diagram Penjualan

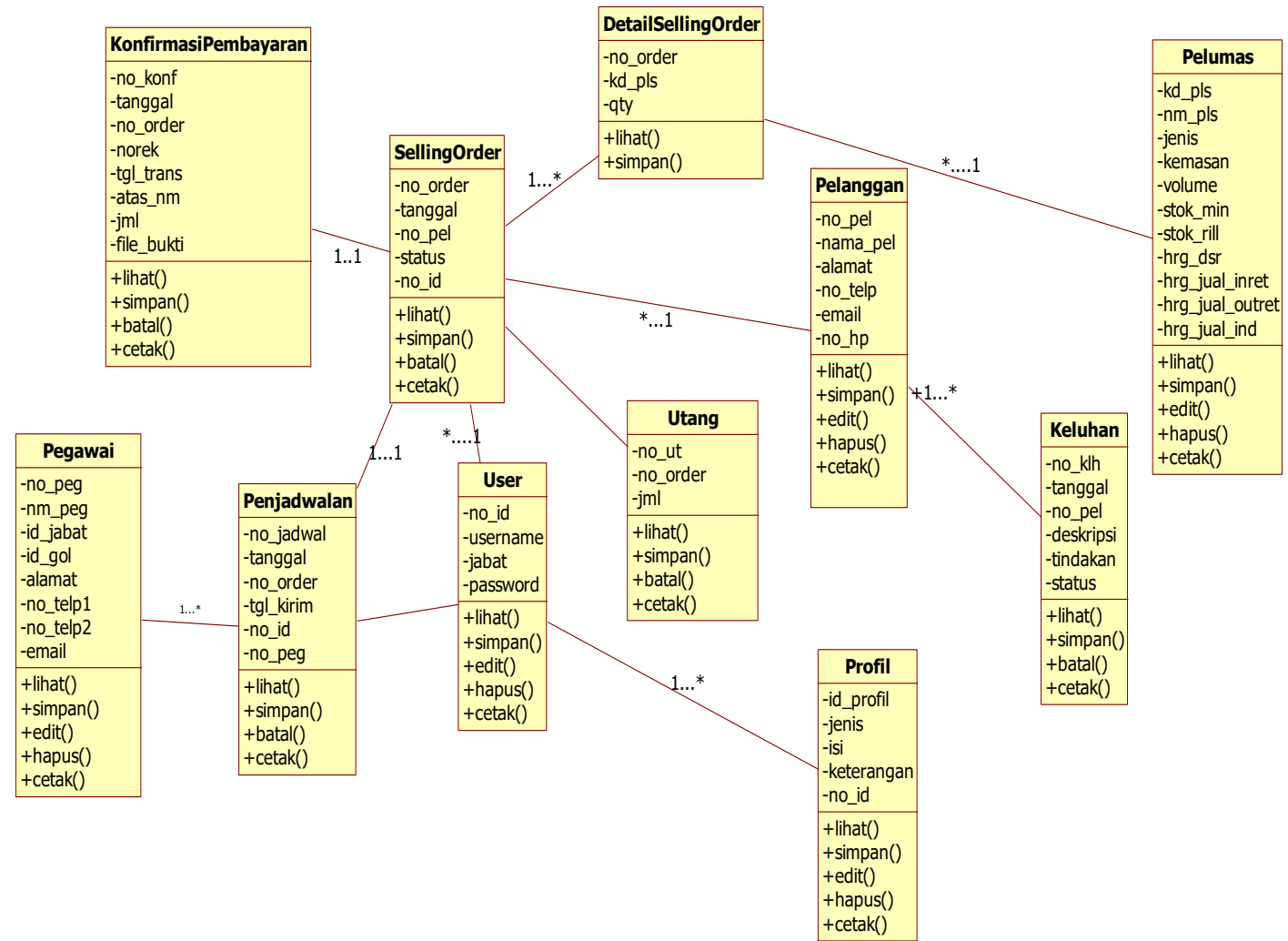

Gambar 10 Class Diagram Sistem Informasi Penjualan

Arsitektur data yang digambarkan pada gambar diatas, merupakan arsitektur data pada sistem informasi penjualan pelumas yang terdiri dari class, atribut dan method. Class dibangun untuk membangun sebuah objek baru dalam sistem ini. Class diagram terdiri dari class profil, pelumas, pelanggan, sellingorder, detailsellingorder, konfirmsipembayaran, penjadwalan, pengiriman, detailpengiriman, keluhan dan user. Atribut terletak pada bagian tengah bagan class dan method berada pada bagian bawah bagan class.

3. Class Diagram Kepegawaian 


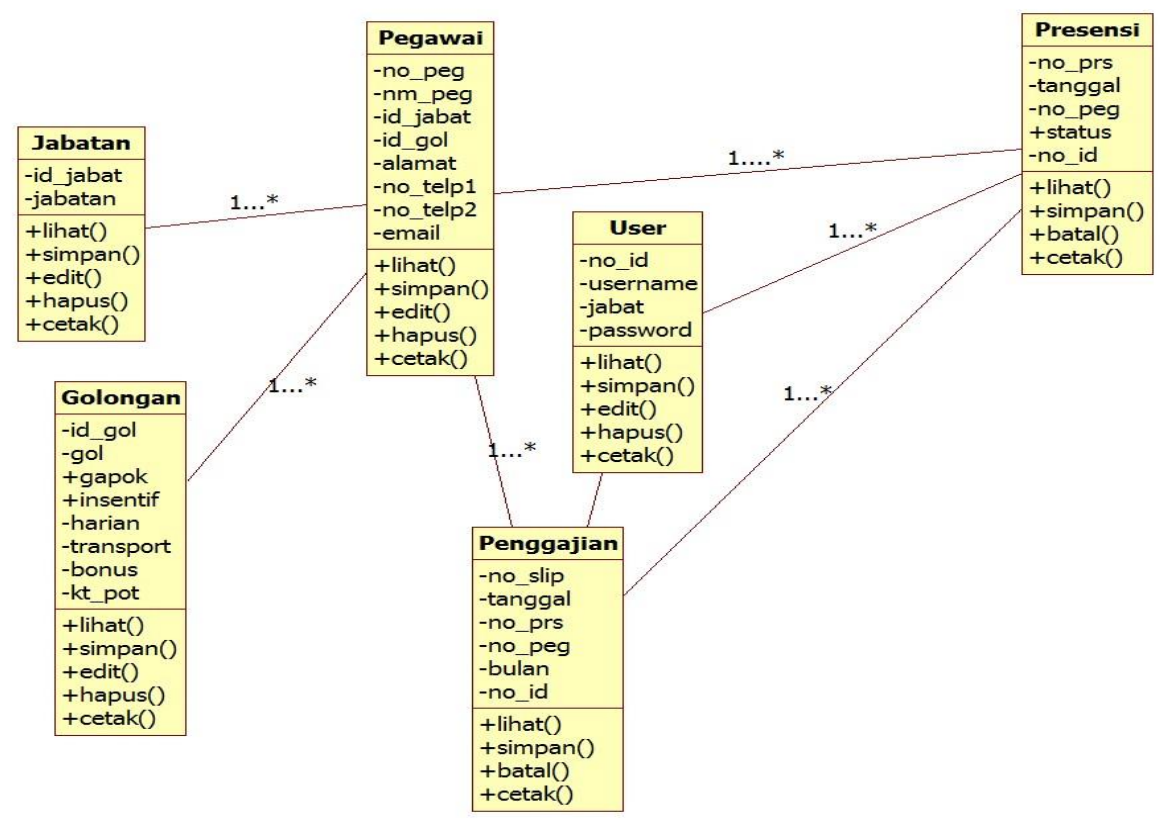

Gambar 11 Class Diagram Sistem Informasi Kepegawaian

Arsitektur data yang digambarkan pada gambar diatas, merupakan arsitektur data pada sistem informasi kepegawaian di PT. Ma'soem Arias yang terdiri dari class, atribut dan method. Class dibangun untuk membangun sebuah objek baru dalam sistem ini. Class diagram terdiri dari jabatan, golongan, pegawai, presensi, penggajian dan user . Atribut terletak pada bagian tengah bagan class dan method berada pada bagian bawah bagan class.

\section{Class Diagram Keuangan}

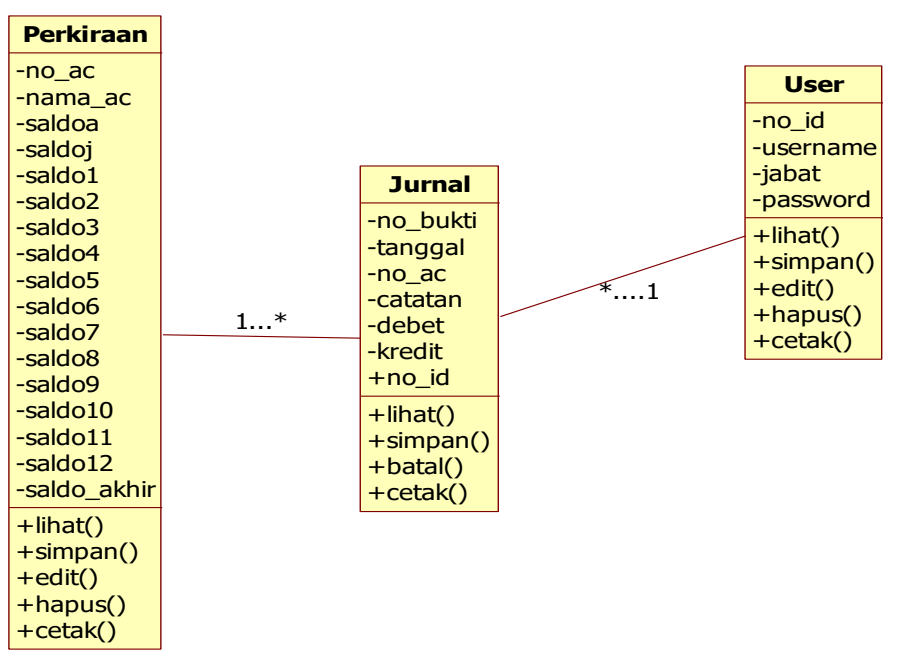

\section{Gambar 12 Class Diagram Sistem Informasi Keuangan}

Arsitektur data yang digambarkan pada gambar diatas, merupakan arsitektur data pada sistem informasi keuangan di PT. Ma'soem Arias yang terdiri dari class, atribut dan method. Class dibangun untuk membangun sebuah objek baru dalam sistem ini. Class diagram terdiri perkiraan dan jurnal. Atribut terletak pada bagian tengah bagan class dan method berada pada bagian bawah bagan class. 


\subsubsection{Arsitektur Teknologi}

Sesuai dengan tahapan arsitktur aplikasi maka diperlukanlah arsitektur teknologi untuk mendukung arsitektur aplikasi yang telah dirancang. Arsitektur jaringan mengacu pada infrastruktur jaringan sesuai dengan analisa sebelumnya bahwa aplikasi yang diusulkan yaitu sistem informasi berbasis website. Berikut usulan untuk arsitektur teknologi di PT. Ma'soem Arias adalah sebagai berikut :

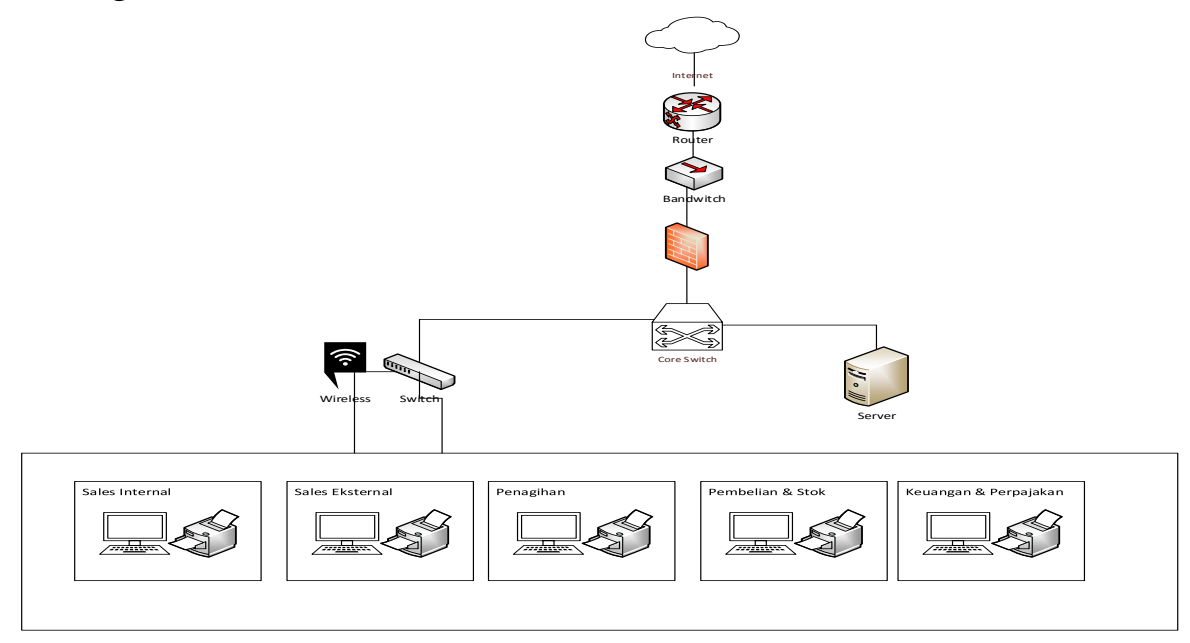

Gambar 13 Arsitektur Jaringan Usulan

Pada gambar diatas, menunjukkan jaringan usulan di PT. Ma'soem Arias, dimana gedung PT. Ma'soem Airas terdiri dari tiga lantai namun untuk kegiatan operasional menggunakan satu lantai saja. Konfigurasi hardware sesuai gambar 13 merupakan sebuah rangkaian struktur jaringan untuk mendukung proses berlangsungnya arsitektur jaringan yang diusulkan berdasarkan analisa sistem pada tahap arsitektur aplikasi baik dari sisi penggunaan software dan hardware pada server area maupun client area.

\subsection{Roadmap Implementasi}

Dalam mengimplementasikan sistem informasi yang telah direkomendasikan pada analisa yang telah dilakukan, maka diusulkan jangka waktu dan durasi untuk mengimplementasikan sistem informasi. Urutan implementasi aplikasi dapat dilihat pada gambar dibawah ini.

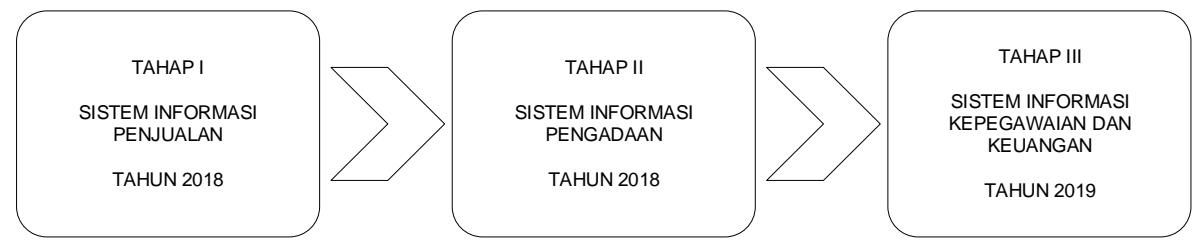

Gambar 14 Urutan Implementasi Sistem Informasi di PT. Ma'soem Arias

Sistem informasi penjualan menjadi urutan yang pertama dalam urutan implementasi karena sistem penjualan merupakan portal yang mengintegrasikan semua sistem. Urutan kedua yaitu sistem informasi pengadaan yaitu sebagai sistem yang membantu mengelola persediaan pelumas berdasarkan stok pelumas, dimana terdapat 3 transaksi utama yaitu purchase order, penerimaan dan pengeluaran. Urutan yang ketiga yaitu sistem informasi kepegawaian dan keuangan.

\section{PENUTUP}

\subsection{Kesimpulan}


Berdasarkan hasil dari analisis yang telah dilakukan oleh peneliti dalam perencanaan arsitektur sistem informasi di PT. Ma'soem Arias dengan menggunakan Oracle Enterprise Architecture Framework (OEAF) maka dapat disimpulkan bahwa :

1. Dalam merancang arsitektur sistem informasi PT. Ma'soem Arias, digunakan metode Oracle Architecture Development Process (OADP) dengan melalui beberapa tahapan meliputi architecture business, architecture vision, current state architecture dan future state architecture.

2. Dalam merancang arsitktur sistem informasi pada PT. Ma'soem Arias yang dimulai dari tahapan architecture business yang menghasilkan pemetaan proses bisnis, tahapan yang kedua yaitu architecture vision dengan hasil keluaran berupa architcture vision untuk PT. Ma'soem Arias, tahapan ketiga yaitu current state arhcitecture yaitu gambaran sistem yang sedang berjalan pada saat ini. Hasil dari penelitian ini yaitu rekomendasi sistem informasi PT. Ma'soem Arias berupa blueprint perencanaan enterprise architecture yang dituangkan pada tahap future state architecture yakni berhasil mendefinisikan 4 proses bisnis utama, pada arsitektur data menghasilkan 24 entitas, 4 aplikasi serta untuk arsitektur teknologinya menghasilkan usulan arsitektur teknologi serta roadmap implementasi untuk mengimplementasikan sistem informasi yang telah direkomendasikan.

\subsection{Saran}

Dengan adanya perencanaan enterprise architecture pada PT. Ma'soem Arias, maka untuk melengkapi hasil kajian penelitian, peneliti menyarankan beberapa hal sebagai berikut:

1. Perencanaan enterprise architecture harus mendapat dukungan dari stakeholder Ma'soem Group.

2. Diharapkan dilakukan analisis biaya untuk pengadaan hardware dan software yang dibutuhkan dalam membangun sistem informasi di PT. Ma'soem Arias.

\section{DAFTAR PUSTAKA}

Agarina, Melda.(2015) Pemanfaatan Framework TOGAF Untuk Perencanaan Sistem Informasi Manajemen Aset Dan Logistik di IBI Darmajaya Bandar Lampung. Informatics and Business Institute Darmajaya.

Babers, Charles. (2006). The Enterprise Architecture Sourcebook (Vol 1). El Paso, TX.

Batley, Sue. (2007). Information Architecture for Information Professionals. Chandos, Oxford.

Benard, Scott A. (2012). An Introduction to Enterprise Architecture. Author House, Bloomington.

Bente, Stefan, Uwe Bombosch and Shailendra Langade. (2012). Collaborative Enterprise Architecture. Elsevier:USA.

Convington, Robert and Hamza Jahangir.(2009). The Oracle Enterprise Architecture Framework. Oracle Corporation. USA.

Ding, Wei, Xia Lin and Michael Zarro. (2017). The Design and Integration of Information Spaces. Morgan \& Claypool. Chapel Hill.

Hadiana, Ana. (2016). Perencanaan \& Pengembangan Sistem Informasi Terpadu. Megatama: Bandung. 
Kridanto, Surendro.(2009). Pengembangan Rencana Induk Sistem Informasi. Informatika:, Bandung.

Marc Lankhorst, Novay and Brouwerijstraat. (2009). Enterprise Architecuture At Work. Springer:, Heilderberg.

Minoli, Daniel. (2008). Enterprise Architecture A to Z: Frameworks, Business Process Modeling, SOA, and Infrastructure Technology. CRC Press.

Munawar.(2005). Pemodelan Visual dengan UML, Graha Ilmu: Yogyakarta.

Porter, Michael.(1985). Competitive Advantage: Creating and Sustaining Superior Performance for Analyzing Industries and Competitor. The Free Press.

Rangkuti, Fredy. (2006). Analisis SWOT Teknik Membedah Kasus Bisnis. PT. Gramedia Pustaka Utama: Jakarta.

Spewak, Steven H. (1992). Enterprise Architecture Planning (Developing a Blueprint for Data, Application and Technology). Jhon Wiley \& Sons,Inc: USA.

Seth, Cristophe. (2015). SWOT Analysis. 50 MinutES:USA.

Sun, Halen, Saen Xu, Paul Silverstein. (2012). Oracle Enterprise Architecture Framework: Information Architecture Domain. Oracle Corporation:USA.

Sutarman. (2012). Buku Pengantar Teknologi Informasi. Bumi Aksara:Jakarta.

Turban, E. dan L. Volonino.(2012). Information Technology for Management. 8th ed. Hoboken:: John Wiley \& Sons.

Wartika dan Supriana Iping.(2011). Analisis Perbandingan Komponen dan Karakteristik Enterprise Architecture Framework. Konferensi Nasional Sistem dan Informatika: Bali.

Yasin, Verdy. (2012). Rekayasa Perangkat Lunak Berorientasi Objek. Mitra Wacana Media. 